\title{
RANCANG BANGUN APLIKASI SIS-LOG IN APPS GUNA MEMPERSINGKAT DISTRIBUSI HASIL PERTANIAN SAYURAN
}

\author{
Afifah Naziihah ${ }^{1}$, Dene Herwanto ${ }^{2}$, Billy Nugraha ${ }^{3}$ \\ ${ }^{123}$ Teknik Industri, Universitas Singaperbangsa Karawang \\ e-mail: afifahnaziihah@gmail.com ${ }^{1}$, deneherwanto@yahoo.com² ${ }^{2}$, billynugraha982@gmail.com ${ }^{3}$
}

\begin{abstract}
Abstrak
Pandemi Covid-19 telah menimbulkan ketidakstabilan di semua sektor, tidak terkecuali sektor pertanian. Sektor yang sanggup bertahan (sector of the last resort) di tengah ancaman pandemi Covid-19. Namun bukan berarti tidak memiliki efek pada kegiatan usaha tani. Padahal pertanian merupakan sektor penopang ketahanan pangan yang menjadi krusial di kala krisis ekonomi. Bukan hanya sebatas bertahan hidup, tapi juga masalah asupan gizi masyarakat. Kreativitas dan inovasi diperlukan dalam sistem rantai pasok. Melalui penjualan produk pertanian langsung dari petani ke konsumen. Hal ini akan menjamin keamanan dan kebersihan kualitas produk sebelum didistribusikan. Maka tujuan penulisan ini membuat e-marketplace pertanian berbasis android yang mudah digunakan. Selain itu penulisan ini menggunakan metode RnD (Research and Development). Dalam metode ini memiliki tahapan ADDIE: (1) Analyze, (2) Design, (3) Development, (4) Implement dan (5) Evaluate. Hasil yang ditawarkan dalam penulisan ini berupa perancangan aplikasi. Aplikasi diberi nama Sis-Log In Apps (Sistem Logistik Pertanian Applications). Berfungsi sebagai perantara jual-beli antara petani dan konsumen. Hasil pengujian menunjukan bahwa semua fungsi dalam aplikasi dapat berjalan baik, sesuai dengan kebutuhan pengguna.
\end{abstract}

Kata kunci: ADDIE Stages, Covid-19 Pandemic, E-Marketplace, RnD Method, Sis-Log In Apps

\begin{abstract}
Pandemic Covid-19 has caused instability in all sectors, not least the agricultural sector. The sector can survive (sector of last resort) in the middle of the threat of the pandemic Covid-19. But that does not mean it has no effect on the activities of the farm. Whereas agriculture is the sector of the cantilever food security becomes crucial in times of economic crisis. Not only survive, but also the problem of the nutrition society. Creativity and innovation is required in the supply chain system. Through the sale of agricultural products directly from farmers to consumers. This will ensure the safety and hygiene quality of the product before it is distributed. The purpose of writing is to make e-marketplace agriculture based on android that is easy to use. In addition, this paper uses the method of RnD (Research and Development). In this method have the stages of the ADDIE: (1) Analyze, (2) Design, (3) Development, (4) Implement and (5) Evaluate. The results provided in this paper form the design of the application. The application is given the name of the Sis-Log In Apps (Sistem Logistik Pertanian Applications). Serves as an intermediary sell-buy between farmers and consumers. The test results showed that all the functions in the application can be run better, according to user requirements.
\end{abstract}

Keywords : ADDIE Stages, Covid-19 Pandemic, E-Marketplace, RnD Method, Sis-Log In

Diterima Redaksi: 30-05-2021 | Selesai Revisi: 23-07-2021 | Diterbitkan Online: 31-07-2021 DOI: https://doi.org/10.23887/janapati.v10i2.34870

\section{PENDAHULUAN}

Covid-19 ialah suatu penyakit menular yang disebabkan oleh jenis corona virus yang baru ditemukan [1]. Virus tersebut membawa penyakit yang pertama kali terjadi di Wuhan, China pada Desember 2019. Covid-19 menjadi pandemi yang terjadi di seluruh dunia [2] dan saat ini ditetapkan sebagai masalah kesehatan internasional. Selain itu, juga menimbulkan ketidakstabilan di semua sektor perekonomian, tidak terkecuali sektor pertanian. Sektor yang sanggup bertahan (sector of the last resort) di tengah ancaman Pandemi Covid-19. Namun bukan berarti pandemi Covid-19 tidak memberikan efek pada kegiatan usaha tani [3]. Padahal pertanian adalah sektor penopang 
ketahanan pangan (food security) yang menjadi krusial di kala krisis ekonomi. Hal ini bukan saja sebatas bertahan hidup, tetapi juga masalah asupan gizi masyarakat [4]

Dilihat dari sisi lain, hal ini dapat menjadi peluang bagi para petani Indonesia. Dikarenakan produk pertanian lokal menjadi tuan rumah di negaranya sendiri [5]. Masyarakat saat ini memang lebih menggemari produk lokal, dikarenakan lebih segar dan terjamin keamanannya [6]. Sehingga kebutuhan masyarakat terhadap produk pertanian pun meningkat. Selain itu ahli gizi juga menyarankan agar masyarakat untuk mengonsumsi makanan sehat dan bergizi. Hal ini untuk meningkatkan sistem kekebalan tubuh di tengah wabah yang melanda. Kreativitas dan inovasi diperlukan dalam sistem rantai pasok. Melalui penjualan produk pertanian langsung dari petani ke konsumen [4]. Teknologi informasi yang sedang berkembang adalah teknologi mobile berbasis android. Saat ini android tidak hanya sebagai sistem operasi perangkat smartphone yang menyediakan ruang untuk berbagai macam aplikasi [7]. Namun salah satu tools yang dapat digunakan untuk merancang dan mengembangkan berbagai macam aplikasi. Maka tujuan penulisan ini membuat emarketplace pertanian berbasis android yang mudah digunakan (user friendly). Aplikasi diberi nama Sis-Log In Apps (Sistem Logistik Pertanian Applications). Berfungsi sebagai perantara jual-beli antara petani dan konsumen. Selain itu mengikuti perkembangan ilmu pengetahuan dan teknologi bagi pertanian Indonesia di masa depan.

Menurut Jony Wong pengertian dari electronic commerce ialah pembelian, penjualan serta pemasaran barang dan jasa melalui sistem elektronik. Seperti radio, televisi dan jaringan komputer atau internet [8]. Selain itu ecommerce adalah proses jual-beli atau tukar menukar produk, jasa atau informasi melalui komputer [9]. Sementara menurut Laudon ecommerce merupakan suatu proses membeli dan menjual produk secara elektronik. Hal ini dilakukan oleh konsumen dan dari perusahaan ke perusahaan dengan menggunakan komputer sebagai perantara transaksi bisnis [10]. Maka pada penulisan ini akan memanfaatkan perkembangan e-commerce ke sektor pertanian. Hal ini dikarenakan e-commerce memiliki peluang yang baik untuk digunakan ditengah Pandemi Covid-19. Menurut Brunn, Jensen dan Skovgaard marketplace adalah wadah bagi komunitas bisnis interaktif secara elektronik yang menyediakan pasar. Melalui sistem kerja perusahaan dapat ambil andil dalam B2B e-commerce dan kegiatan ebusiness lainnya [11].

Android merupakan platform pertama yang terbuka dalam pengembangannya dan komperehensif untuk perangkat mobile. Perangkat lunak yang difungsikan dapat menjalankan device mobile. Tanpa memikirkan kendala kepemilikan yang menghambat inovasi teknologi mobile [12]. Unified Modelling Language (UML) adalah bahasa pemodelan untuk sistem atau perangkat lunak yang berparadigma berorientasi objek. Konsep dasar UML terdiri dari: structural classification, dynamic behavior dan model management. Hal ini dapat dipahami melalui main concepts sebagai term yang akan muncul pada saat membuat diagram dan view. UML menjelaskan berbagai diagram sebagai use case diagram, class diagram, statechart diagram, activity diagram, sequence diagram, collaboration diagram, component diagram dan deployment diagram [13].

Berikut beberapa hasil penulisan/penelitian terdahulu yang dijadikan parameter dalam melakukan penelitian. Penelitian yang dilakukan oleh Deni Apriadi dan Arie Yandi Saputra: Hasil penelitian menunjukan aplikasi e-commerce berbasis marketplace ini, dapat digunakan oleh petani dalam memasarkan hasil pertanian mereka secara langsung ke konsumen. Sehingga rantai distribusi pemasaran dapat dipotong dari hal ini akan berimbas pada keuntungan bagi petani [14]. Penelitian yang dilakukan oleh I Made Resza Surya Adinata, Herman Tolle dan Adam Hendra Brata: Hasil penelitian menunjukan bahwa hasil implementasi sistem untuk aplikasi penjualan hasil panen kelompok tani untuk konsumen adalah dengan membangun sebuah aplikasi mobile berbasis android penjualan hasil panen dengan bahasa pemrograman kotlin ke dalam platform sistem operasi android [15]. Penelitian yang dilakukan oleh Meylanie Olivya dan Ilham: Hasil penelitian menunjukan bahwa sistem informasi pemasaran hasil bumi di Kabupaten Enrekang ini berhasil dibuat dan dapat dijadikan acuan oleh masyarakat untuk memperoleh informasi mengenai harga tanaman pertanian dan perkebunan dengan mudah dan tepat dikarenakan proses aplikasi ini berjalan secara real time [16]. Penelitian yang dilakukan oleh Handrio Madesko: Hasil penelitian menunjukan dengan adanya aplikasi ini dapat memudahkan dalam memasarkan produk hasil pertanian yang dibantu oleh instansi desa yaitu bagian UKM. Dengan adanya aplikasi ini sangat membantu memperluas jaringan penjualan ke daerah 
daerah di luar dari Desa Panjang Hilir Inuman [17]. Penelitian yang dilakukan oleh Ahmad: Hasil penelitian menunjukan Aplikasi komoditas pertanian yang dibuat dapat memberikan kemudahan bagi masyarakat khususnya petani dalam mengakses informasi mengenai komoditas pertanian, seperti harga, varietas tanaman, produksi dan hal lain yang berkaitan dengan komoditas pertanian melalui perangkat smartphone atau tablet $\mathrm{pc}$ yang berbasis android [18].

Sedangkan beberapa hasil penulisan/penelitian terdahulu lainnya yang dijadikan sebagai alternatif parameter penelitian. Penelitian yang dilakukan oleh Heru Nugroho, Robbi Hendriyanto dan Kautsar Tisamawi: Hasil penelitian menunjukan bahwa aplikasi untuk pasar produk pertanian memfasilitasi petani ke pasar produk mereka dengan cepat dan efisien untuk mencari sayuran atau buah yang dijual di Indonesia serta transaksi antara pembeli dan petani menjadi lebih mudah dan lebih cepat [19]. Penelitian yang dilakukan oleh $\mathrm{CH}$. L. Soundarya, M. Preethi, D. Kavya, S. Sai Keerthana dan Suhasini Sodagudi: Hasil penelitian menunjukan bahwa Melalui aplikasi mobile ini bisa pastikan itu menguntungkan dan keuntungan untuk kedua pihak, petani atau produsen dan konsumen [20]. Penelitian yang dilakukan oleh Lily Beaulah dan Latha: Hasil penelitian menunjukan bahwa aplikasi menghentikan sebagian besar aktivitas mediator dengan opsi jual atau beli langsung ke petani/pembeli. Aplikasi sangat membantu dan memecahkan sebagian besar masalah petani serta membantu dalam membimbing mereka dengan cara terbaik tentang pertanian [21]. Penelitian yang dilakukan oleh Sumitra Nuanmeesri: Hasil penelitian menunjukan bahwa, mobile application dapat secara efektif digunakan sebagai alat untuk mendukung petani dalam mendistribusikan produk pertanian mereka dalam satu-stop pasokan rantai [22]. Penelitian yang dilakukan oleh Kingshuk Dhar, Shatilekha Barua, Aishwariya Dey dan
Uaschash Barua: Hasil penelitian menunjukan bahwa aplikasi akan mengurangi harga mendadak yang dibuat oleh perantara dengan menjual atau membeli langsung ke petani atau pembeli [23].

Sistem pemasaran pertanian berbasis teknologi informasi akan membuat petani lebih mudah untuk menjual hasil panen. Sehingga petani akan menghemat lebih banyak waktu dan biaya untuk mendapatkan konsumen [23]. Aplikasi jual beli hasil pertanian muncul dari permasalahan petani yang sulit untuk memasarkan produk pertanian. Hal ini karena adanya perantara yang memainkan harga pasar. Pada saat ini teknologi e-commerce salah satu inovasi yang dapat digunakan untuk membantu petani. Dalam hal memasarkan produk dan dapat memotong distribusi pemasaran produk pertanian. Dalam penelitian kali ini, diusulkan membuat aplikasi android yang lebih fleksibel dengan mengurangi kompleksitas. Sis-Log In Apps berbasis android dirancang lebih bersahabat dan mudah digunakan. Selain itu mudah dimengerti jika dibandingkan dengan aplikasi yang telah dikembangkan pada penelitian sebelumnya maupun marketplace jual beli hasil pertanian yang telah dikenal oleh masyarakat seperti Sayurbox atau Tanihub karena Sis-Log In Apps hanya terbatas pada produk hasil pertanian yang dikategorikan ke dalam 8 kelompok sayuran: sayuran daun, sayuran batang, sayuran bunga, sayuran buah, sayuran umbi, sayuran polong-kacang, sayuran umbi lapis, sayuran jamur.

\section{METODE}

Penelitian ini dilakukan dengan pendekatan $\mathrm{RnD}$ (Research and Development) untuk menemukan jawaban atas permasalahan yang ada. RnD digunakan untuk menghasilkan sebuah produk tertentu yang disertai pengujian keefektifan produk tersebut [24] Berikut ini adalah tahapan yang dilakukan dalam mengembangkan Sis-Log In Apps. Seperti pada Gambar 1. di bawah ini. 


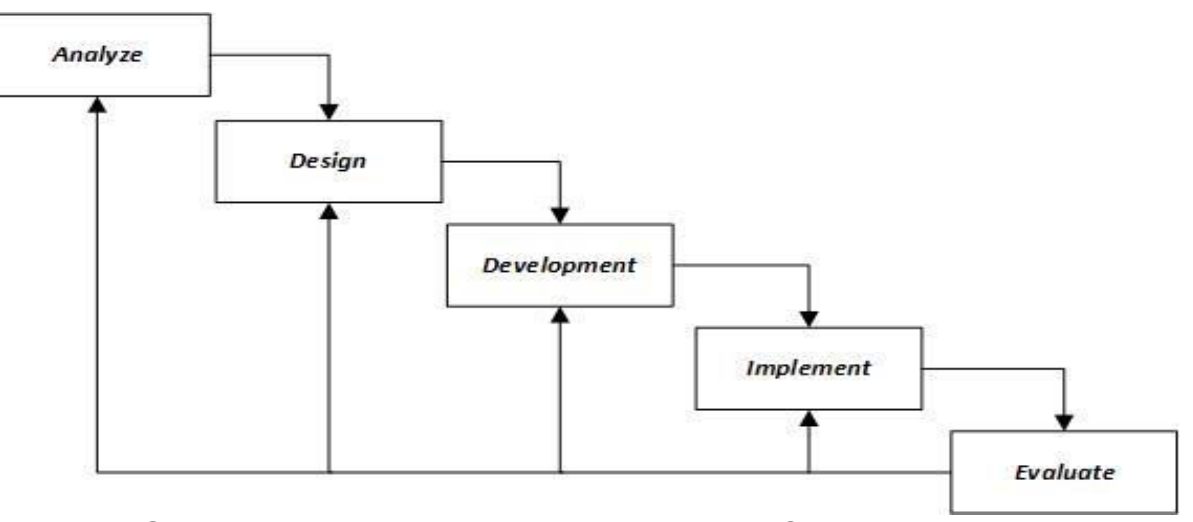

Gambar 1. Diagram Alur Pengembangan Sis Log In Apps

Berdasarkan Gambar 1. di atas merupakan tahapan/alur pengembangan yang telah dilakukan. Pengembangan Sis-Log In Apps menggunakan tahapan ADDIE: Analyze, Design, Development, Implement dan Evaluate. Model ADDIE dinilai sangat cocok untuk penelitian yang fokus pada pengembangan analisis instruksional dan perancangan sistem [25]. Sebelum pada tahap analyze dilakukan identifikasi masalah. Hal ini bertujuan untuk menentukan rumusan, tujuan dan manfaat dari hasil penelitian yang dilakukan. Penelitian ini menggunakan studi literatur dan lapangan. Pada studi literatur berdasarkan hasil telaah pustaka, seperti: jurnal/buku/prosiding. Sedangkan pada studi lapangan melalui observasi langsung, wawancara dan pengisian kuesioner dengan kelompok usaha tani di Kecamatan Telukjambe, Karawang. Pada tahap design merupakan tahapan perancangan yang terdiri: (1) Use Case Diagram, (2) Activity Diagram, (3) Entity Relationship Diagram dan (5) Design Interface. Selanjutnya tahap development, pada tahapan ini rancangan kemudian diimplementasikan ke dalam bahasa pemorgraman, database, perangkat lunak dan perangkat keras. Tahap Implement yaitu proses instalasi dan alur penggunaan aplikasi. Selain itu dilakukan uji kelayakan aplikasi dengan menggunakan black box testing dan uji profitability. Tahap evaluate menjelaskan terkait dengan hasil pengembangan dan pengujian sistem. Jika terdapat ketidaksesuaian aplikasi terhadap kebutuhan pengguna atau ketidaksempurnaan kinerja aplikasi, maka diperlukan perbaikan atau maintenance pada tahap yang dinyatakan bermasalah.

\section{HASIL DAN PEMBAHASAN Analysis}

Pada tahap ini peneliti melakukan identifikasi terhadap permasalahan yang ditemukan. Sehingga dapat dijadikan landasan untuk mengembangkan Sis-Log In Apps. Hasil survei sosial demografi dampak Covid-19 oleh Badan Pusat Statistik (BPS) yang dirilis Juni 2020, menunjukkan 9 dari 10 responden memilih berbelanja dalam jaringan (daring/online), dibandingkan berbelanja di pasar swalayan atau tradisional. Sistem yang akan dirancang adalah aplikasi jual-beli hasil pertanian sayur-sayuran berbasis android. Aplikasi ini dapat diakses oleh petani dan konsumen. Selain itu menyajikan tentang jenis produk sayuran, deskripsi, foto dan harga produk serta informasi kontak petani untuk pemesanan. Analisis masalah dan penyelesaiannya dilakukan dengan wawancara dan penyebaran kuesioner kepada kepada 11 orang kelompok usaha tani yang dipilih berdasarkan 8 kategori sayuran hasil pertanian yang dihasilkan dan 4 orang penyuluh pertanian di Desa Linggarsari, Kecamatan Telagasari, Kabupaten Karawang. Hasil dari observasi dan wawancara langsung menggunakan teknik wawancara terstruktur sebagai berikut:

1. Kurangnya pengetahuan petani dalam memanfaatkan teknologi pada saat ini.

2. Pemasaran hasil pertanian yang sulit dan sering kali diberi harga rendah oleh pengepul.

3. Petani hanya memasarkan hasil pertanian di dekat tempat pertanian tersebut. Selain itu proses transaksi tidak bisa langsung dilakukan antara penjual dan pembeli, melainkan melalui tengkulak atau pengepul terlebih dahulu.

Berdasarkan hasil kuesioner untuk calon pengguna Sis-Log In Apps yang telah dilakukan terdapat beberapa masalah yaitu:

1. $39 \%$ responden membeli sayuran di warung sayuran yang menyebabkan harga jual akhir sayuran yang semakin mahal karena melalui beberapa pengepul.

2. $48 \%$ responden mempertimbangkan adanya aplikasi jual-beli sayuran untuk memudahkan transaksi jual beli yang bisa diakses dengan mudah. 
3. $78 \%$ responden memilih metode cash on delivery (COD) atau bayar di tempat karena dianggap mudah dilakukan.

Berdasarkan analisis permasalahan tersebut, maka solusi yang dapat diusulkan adalah dengan membuat aplikasi e-marketplace pertanian. Selain itu berbasis android yang mudah digunakan (user friendly), yang diberi nama Sis-Log In Apps (Sistem Logistik Pertanian Applications). Aplikasi yang dikembangkan ini dapat dijadikan penyelesaian masalah yang menjadi temuan peneliti:

1. Sis-Log In Apps memfasilitasi para petani (penjual) untuk menjual hasil panennya kepada konsumen secara langsung, tanpa melalui perantara atau pengepul terlebih dahulu.

2. Sis-Log In Apps menyediakan produk-produk hasil pertanian yang dikategorikan ke dalam 8 kelompok sayuran: sayuran daun, sayuran batang, sayuran bunga, sayuran buah, sayuran umbi, sayuran polong-kacang, sayuran umbi lapis, sayuran jamur.

3. Sis-Log In Apps dilengkapi dengan fitur urutkan berdasarkan harga. Sehingga akan membuat penggunan dapat dengan mudah memilih jenis produk dan harga yang diinginkan.

Berdasarkan analisis masalah dan penyelesaiannya pada pengembangan Sis-Log In Apps. Didapatkan beberapa kebutuhan fungsional sebagai berikut:

1. Analisis Kebutuhan Fungsional

Hal yang berperan pada aplikasi terdiri: kelompok tani sebagai penjual hasil panen dan konsumen sebagai pembeli hasil panen. Tabel 1. di bawah menampilkan daftar kebutuhan pada kelompok tani sebanyak 9 kebutuhan fungsional.

Tabel 1. Kebutuhan Fungsional Kelompok Tani

\begin{tabular}{ll}
\hline Kode & \multicolumn{1}{c}{ Keterangan } \\
\hline SL01 & Melakukan login dan logout \\
SL02 & Melihat akun petani \\
SL03 & Mengedit akun petani \\
SL04 & Menambah hasil panen \\
SL05 & Menampilkan hasil panen \\
SL06 & Mengubah stok hasil panen \\
SL07 & Menghapus hasil panen \\
SL08 & Mengubah harga hasil panen \\
\hline
\end{tabular}

Sedangkan pada Tabel 2. di bawah menampilkan daftar kebutuhan fungsional pada bagian konsumen, dengan perolehan sebanyak 7 kebutuhan fungsional.

Tabel 2. Kebutuhan Fungsional Konsumen

\begin{tabular}{ll}
\hline Kode & \multicolumn{1}{c}{ Keterangan } \\
\hline SL01 & Melakukan login dan logout \\
SL02 & Melihat akun pembeli \\
SL03 & Mengedit akun pembeli \\
SL04 & Menampilkan daftar kelompok \\
& tani \\
SL05 & Menampilkan hasil panen \\
SL06 & Mencari produk hasil panen \\
SL07 & Melihat profil petani \\
\hline
\end{tabular}

2. Kebutuhan Non fungsional

Berdasarkan analisis pada pengembangan Sis-Log In Apps. Terdapat beberapa kebutuhan non fungsional [26] [27] sebagai berikut:

a. Portability, aplikasi harus dapat digunakan pada perangkat mobile android.

b. Compatibility, berjalan pada android minimal versi 5.1 lollipop.

c. Usability, aplikasi dengan tampilan userfriendly dengan tujuan agar memudahkan pengguna dalam memakai aplikasi.

d. Reliability, dapat menjalankan aplikasi tanpa mengakibatkan crash terhadap aplikasi berjalan lainnya.

\section{Design}

Perancangan sistem dilakukan sesuai spesifikasi dan kebutuhan sistem yang dianalisis pada tahap sebelumnya. Beberapa diagram diperlukan untuk memperjelaas dan medeskripsikan fitur serta alur kerja sistem. Sehingga tahapan ini akan menghasilkan sebuah sistem yang detail dan terstruktur.

1. Pemodelan Use Case (Interaksi Pengguna dengan Sistem)

Permodelan use case diagram diperoleh melalui dokumentasi kebutuhan fungsional pengguna. Selain itu berguna untuk memberikan gambaran fungsi yang dimiliki pada aplikasi. Dari hasil analisis kebutuhan fungsional yang telah didefinisikan, maka didapatkan use case diagram,seperti pada Gambar 2 di bawah ini. 
2. Activity Diagram

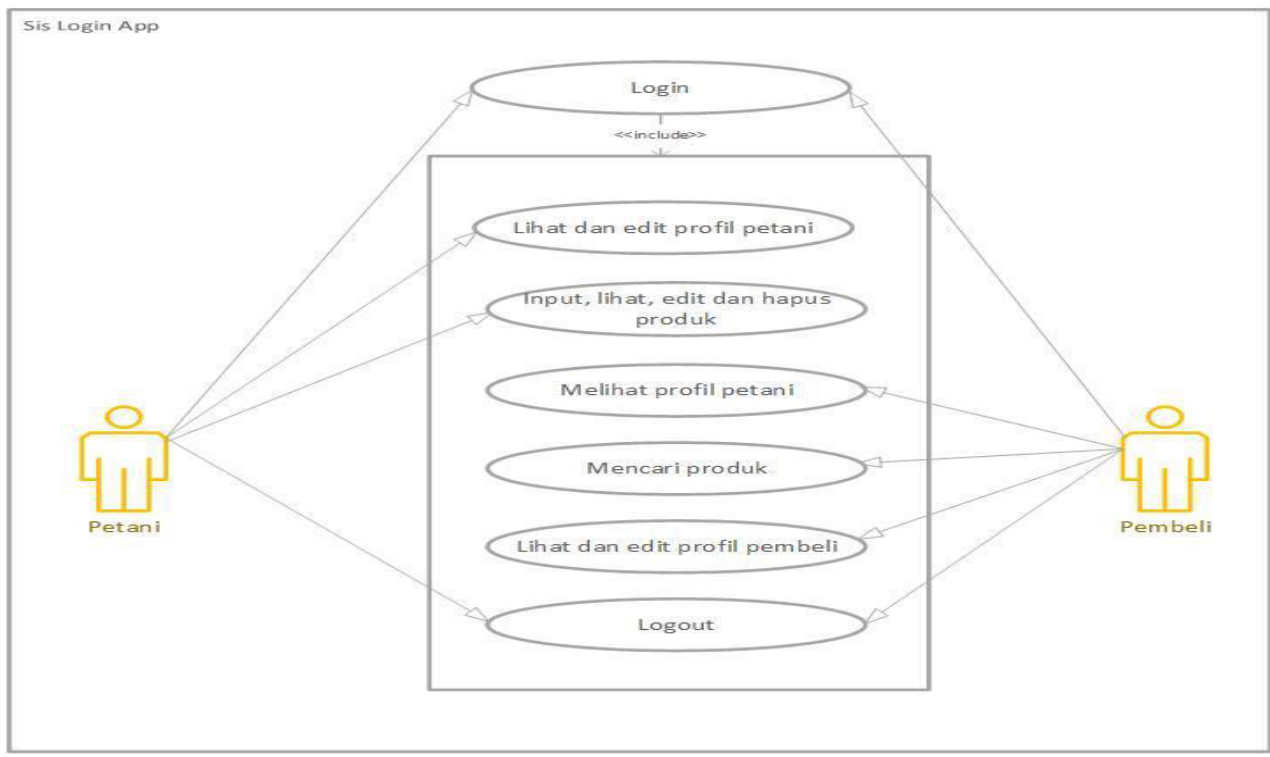

Gambar 2. Pemodelan Use Case Sis-Log In Apps

a. Activity Diagram untuk Daftar Pengguna

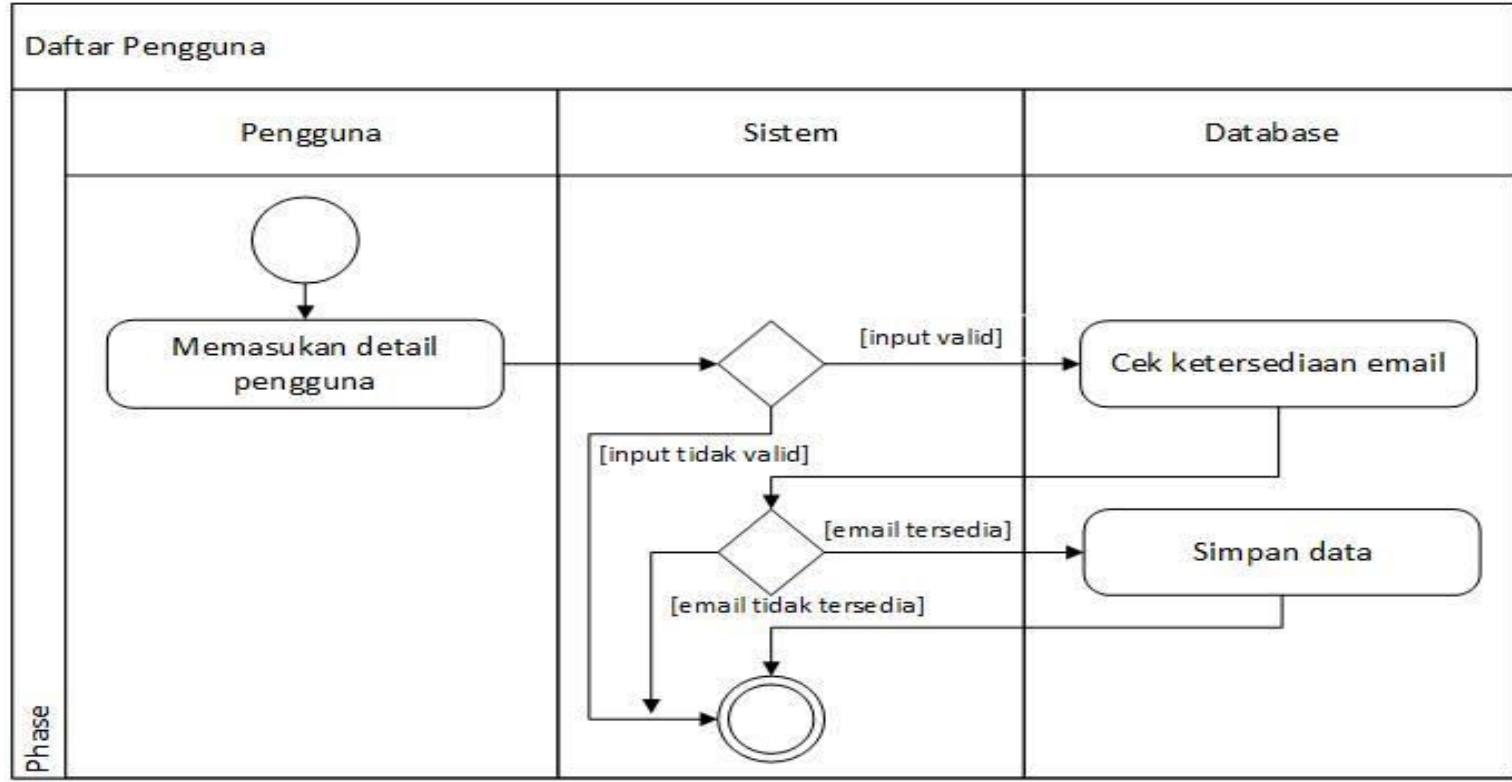

Gambar 3. Activity Diagram untuk Daftar Pengguna

Pada Gambar 3. di atas merupakan activity diagram untuk daftar pengguna. Hal ini Untuk mendaftar akun petani atau pembeli. Pengguna harus memasukan beberapa data terlebih dahulu. Data yang dimasukkan akan dicek melalui email sudah tersedia atau tidak. Jika data semua valid maka pendaftaran akun berhasil. b. Activity Diagram untuk Login Pengguna Pada Gambar 4. di bawah adalah activity diagram untuk login pengguna yaitu petani dan pembeli. Data yang dimasukan ke dalam aplikasi yaitu username berupa email dan password. Jika username dan password valid maka user akan diarahkan ke interface home. 


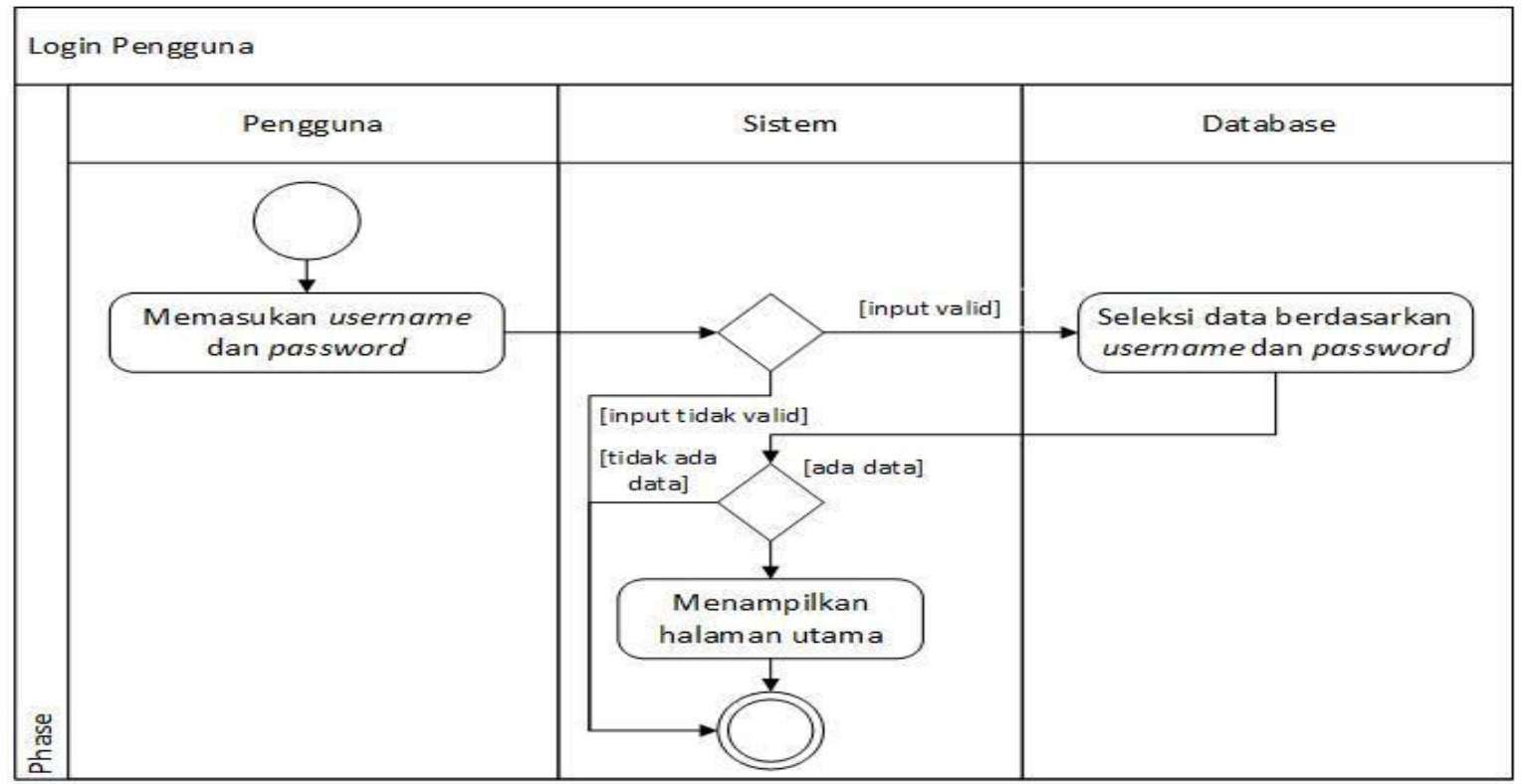

Gambar 4. Activity Diagram untuk Login Pengguna

harus menginput detail produk. Sementara jika data produk tidak valid

c. Activity Diagram untuk Input Produk

Pada Gambar 5. di bawah merupakan activity diagram untuk input produk. Petani yang ingin menjual produk maka penjualan tidak dapat dilakukan. Sedangkan Jika semua data valid maka data akan disimpan di database.

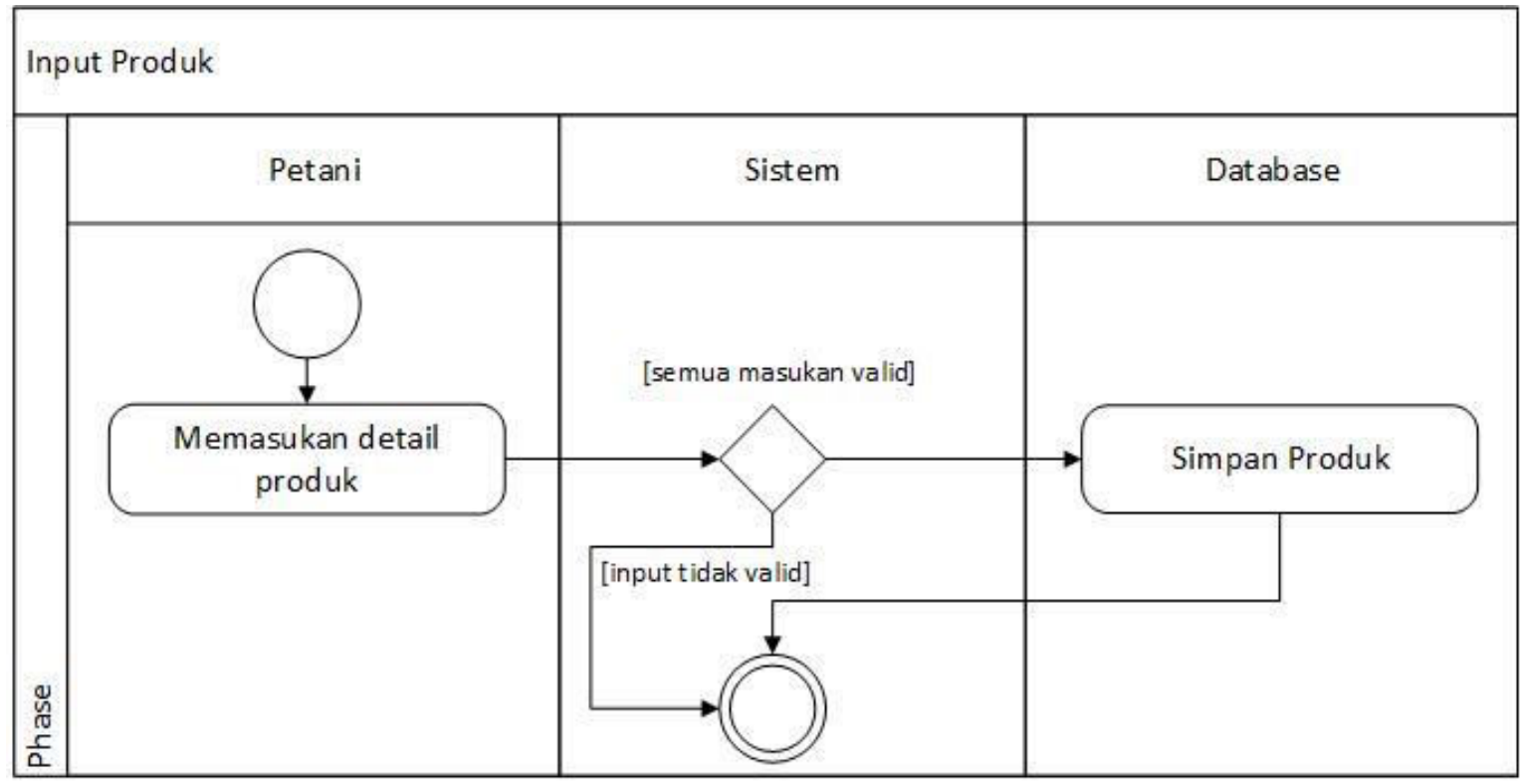

Gambar 5. Activity Diagram untuk Input Produk

d. Activity Diagram Mencari Produk

Pada Gambar 6. di bawah merupakan activity diagram mencari produk yang di jual oleh petani. User yang mencari produk hasil pertanian akan memasukan nama atau kata kunci produk. Kemudian nama produk atau kata kunci akan dicari dalam database dan ditampilkan dalam sistem jika ada. 


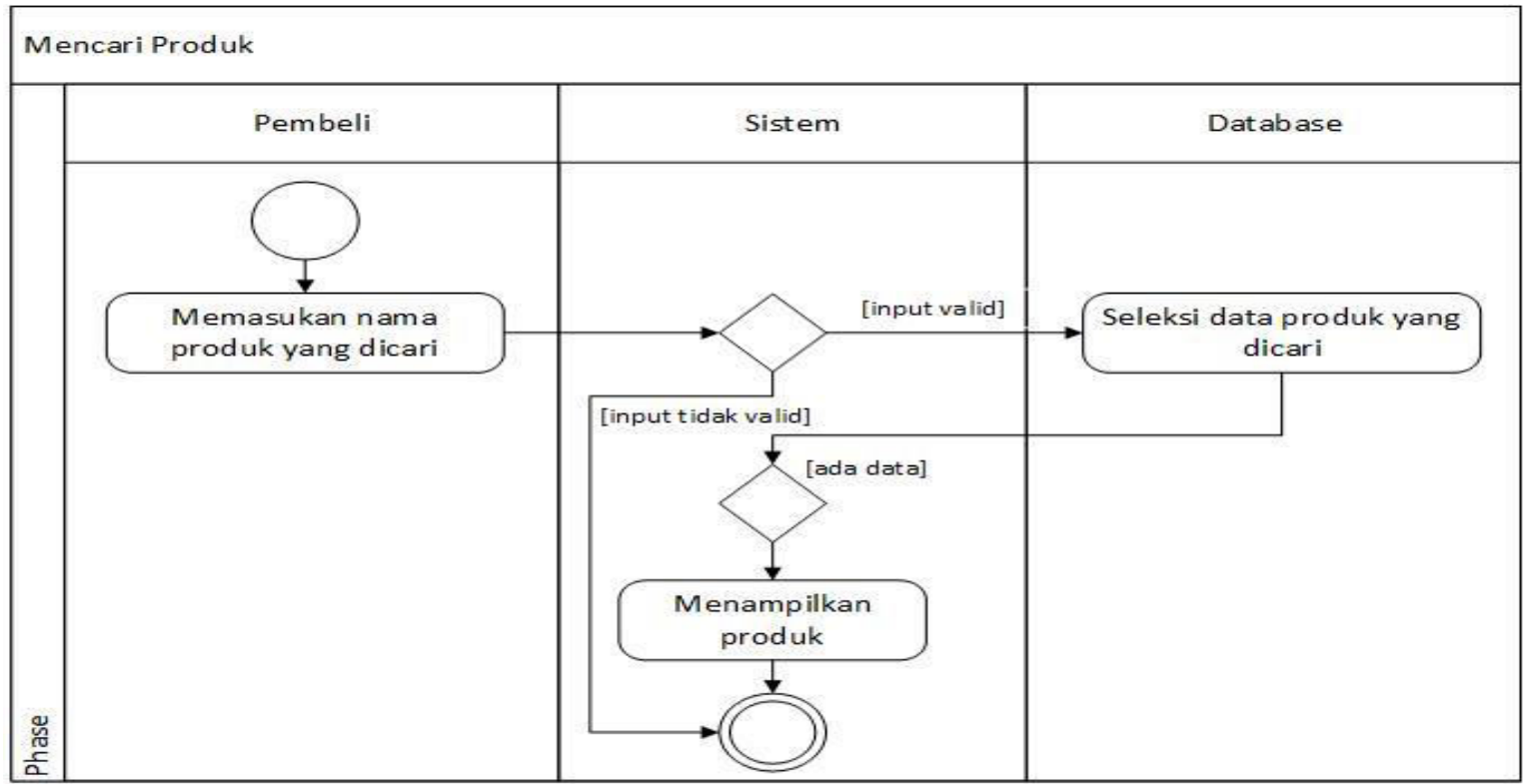

Gambar 6 Activity Diagram untuk Mencari Produk

e. Activity Diagram untuk Melihat Produk

Pada Gambar 7. di bawah merupakan activity diagram untuk melihat produk yang di jual oleh petani. User yang melihat produk hasil pertanian akan memilih produk yang sesuai. Kemudian ID produk yang didapat akan dicari dalam database dan ditampilkan dalam sistem.

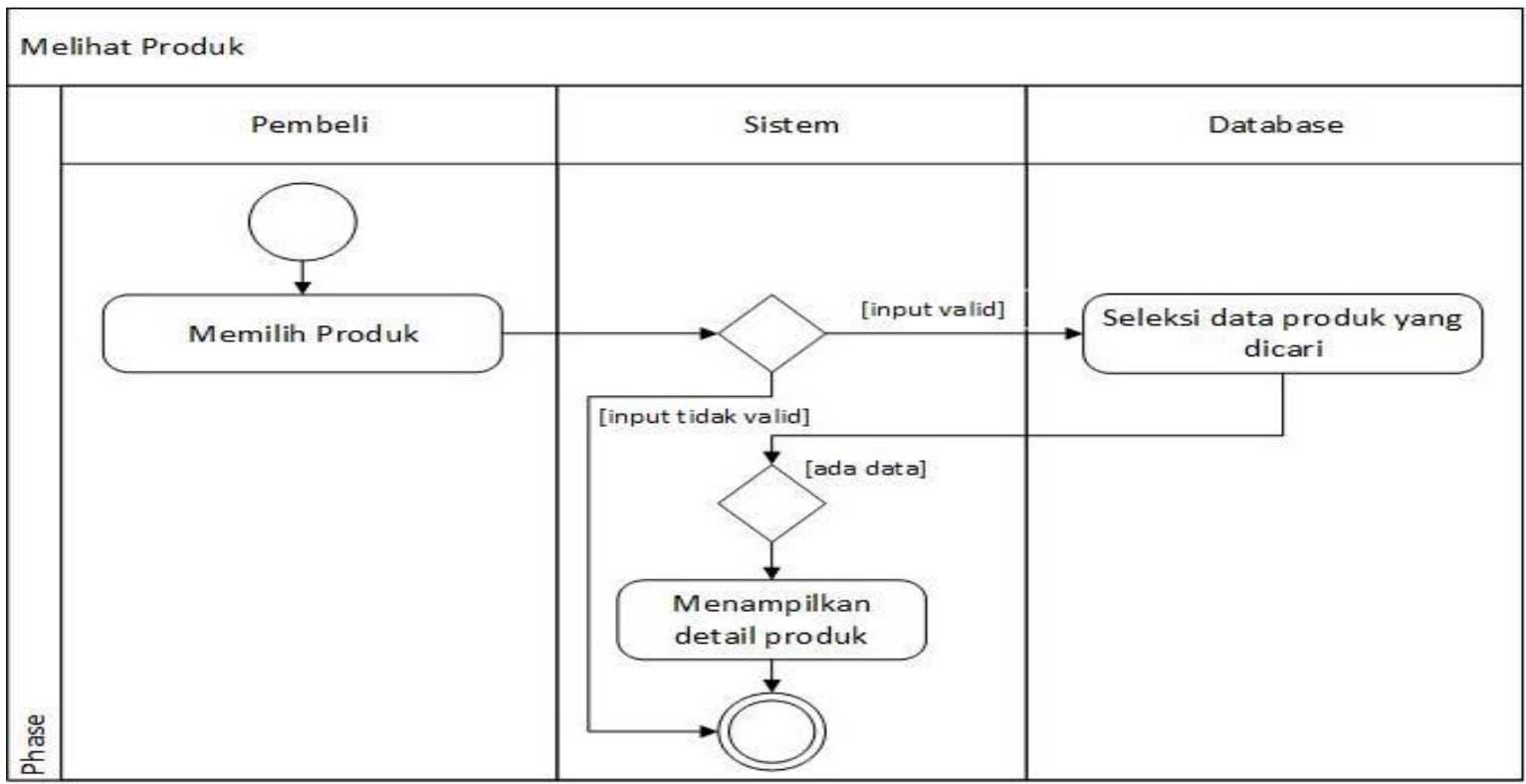

Gambar 7. Activity Diagram untuk Melihat Produk

3. Entity Relationship Diagram (ERD)

Perancangan database ini digunakan untuk melakukan proses coding. Dalam entity relationship diagram akan terlihat atribut dalam entitas dan juga hubungan antar entitas. Hasil dari entity relationship diagram yang telah dirancang. Seperti pada Gambar 8. di bawah ini: 


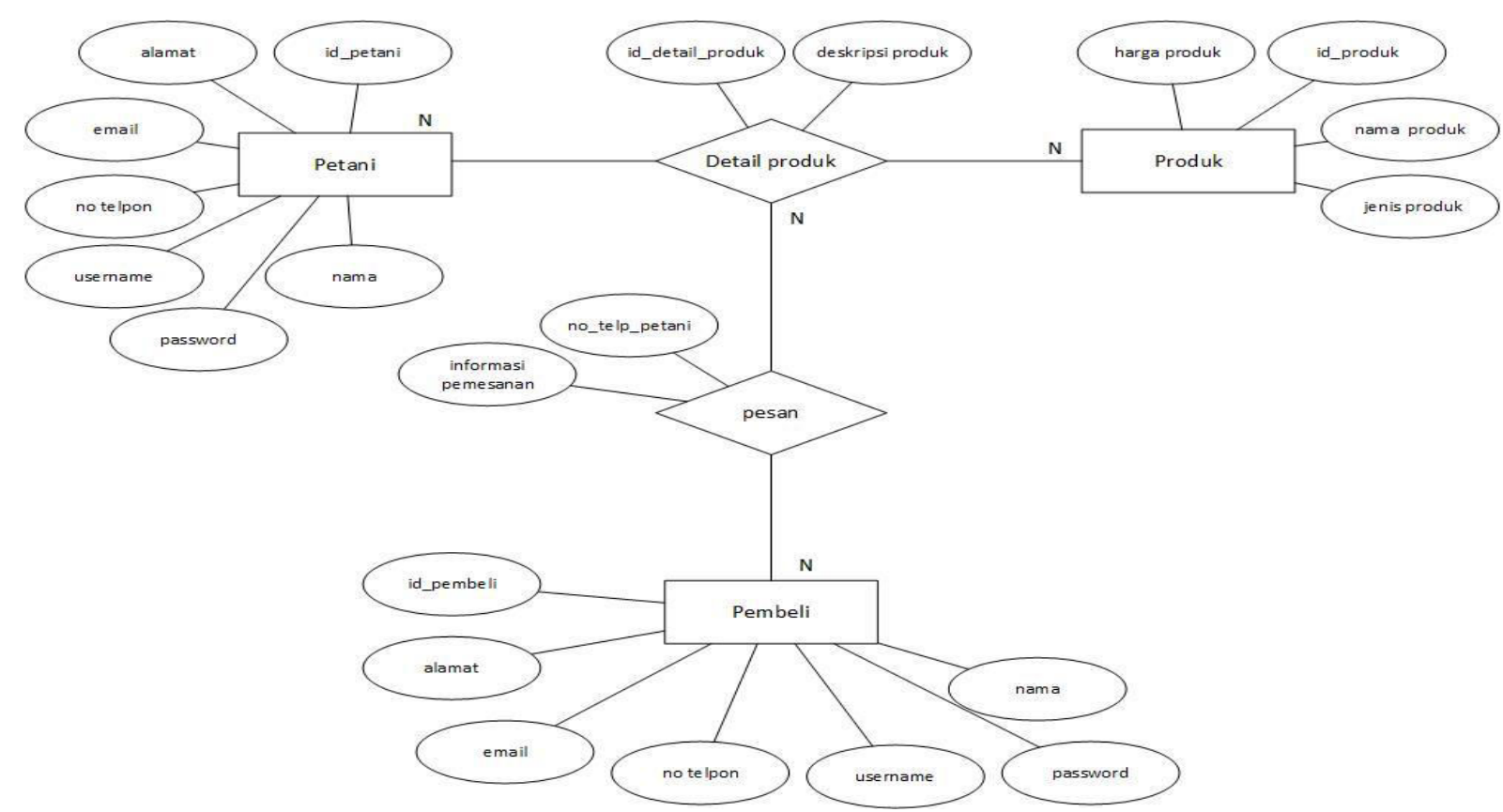

Gambar 8. Activity Diagram untuk Melihat Produk

4. Perancangan Interface

Pada tahap selanjutnya dilakukan perancangan interface aplikasi, dengan membuat rancangan tampilan dari Sis-Log In Apps yang berfungsi untuk menghubungkan pengguna agar dapat berinteraksi dengan perangkat lunak aplikasi. Aplikasi ini memiliki rancangan interface yang sederhana, user friendly, dan dipahami oleh pengguna.

\section{Development}

Pada pengembangan Sis-Log In Apps, arsitektur perangkat lunak yang telah dirancang. Selanjutnya dikembangkan sehingga dapat memenuhi seluruh kebutuhan fungsional dan non fungsional yang sudah ditentukan. Berikut hasil perancangan Sis-Log In Apps yang telah dikembangkan dengan tahapan pengembangan model di atas. Dengan masing-masing penjelasan sebagai berikut:

1. Halaman Awal dan Daftar Pengguna
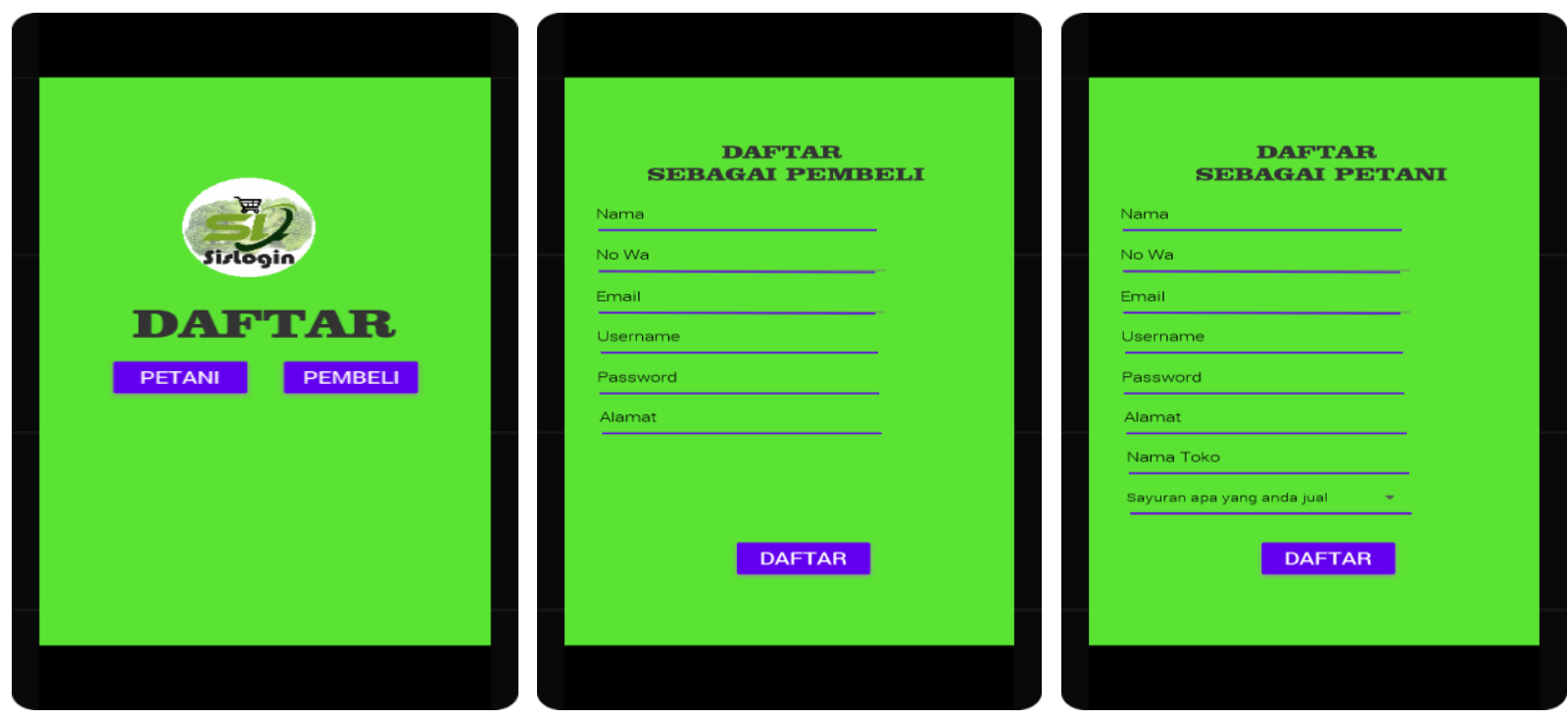

Gambar 9. Halaman Awal dan Daftar Pengguna

Pada Gambar 9. di atas merupakan halaman awal Sis-Log In Apps. Halaman awal merupakan splash screen, pada halaman ini memuat tombol perintah. berfungsi untuk masuk atau daftar untuk pengguna. Saat pengguna menekan tombol 
daftar pada splash screen. Maka pengguna akan berada di halaman daftar awal (untuk pengguna baru). Selain itu terdapat pilihan untuk daftar sebagai pembeli atau petani.

2. Halaman Masuk dan Halaman Utama
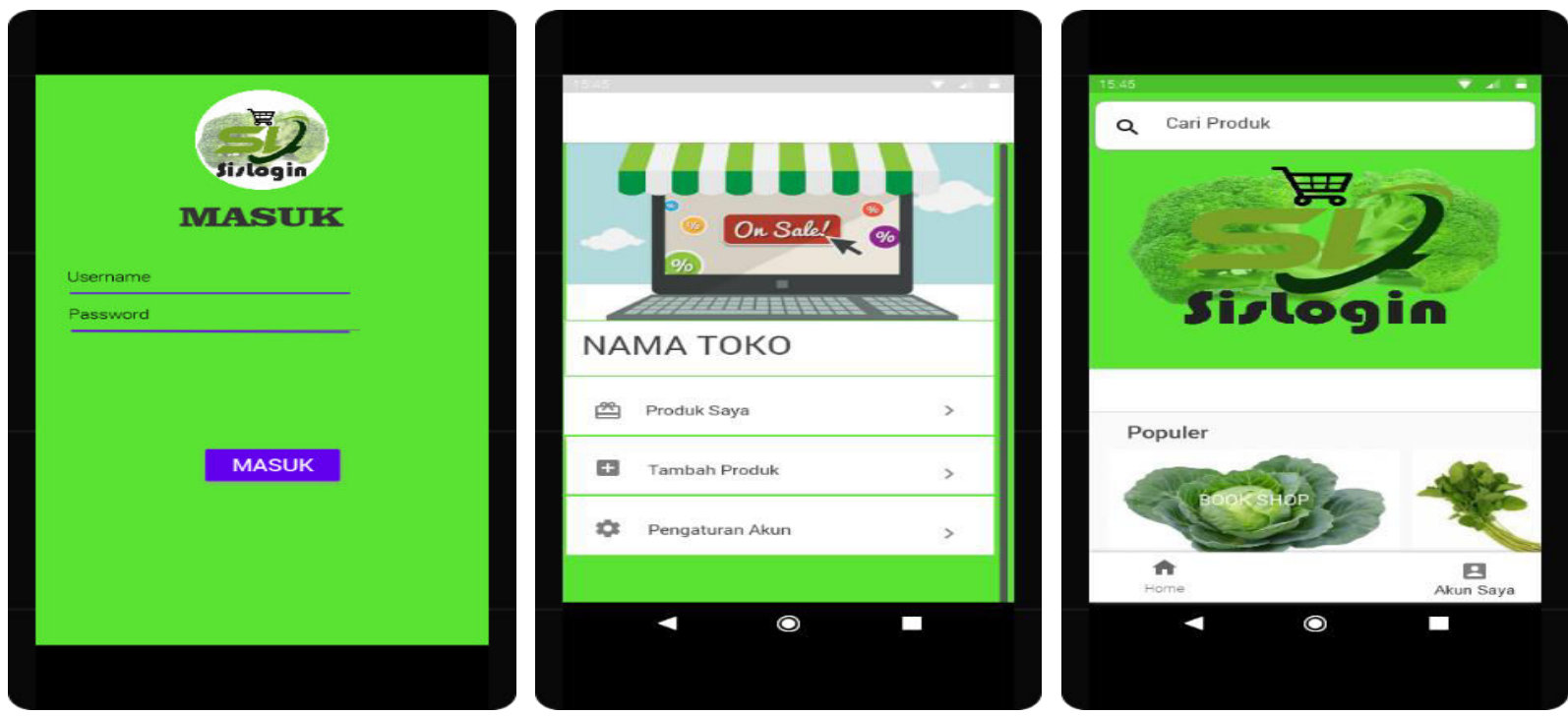

Gambar 10. Halaman Masuk dan Halaman Utama

Selanjutnya pada Gambar 10. di atas merupakan halaman masuk dan halaman utama. Setelah selesai daftar, pengguna menekan tombol masuk sebagai pembeli atau petani. Maka pengguna akan berada di halaman masuk. Hal ini harus memasukkan userrname dan password. Jika berhasil masuk, pengguna akan berada di halaman utama.

3. Halaman Input Produk dan Etalase Toko
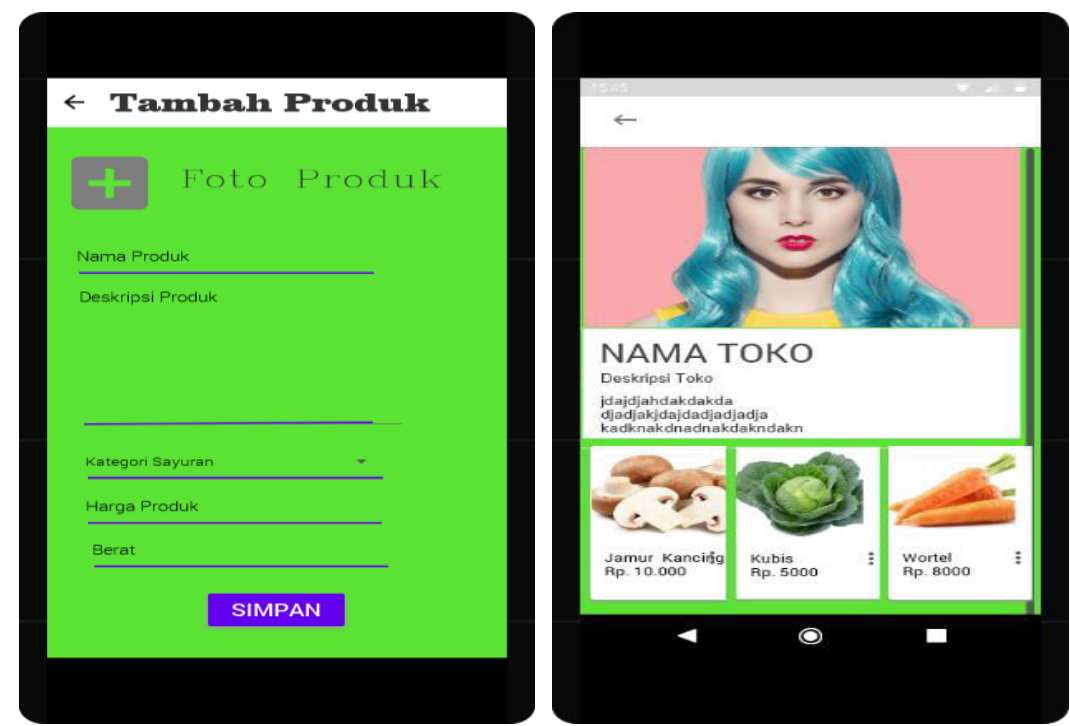

Gambar 11. Halaman Input Produk dan Etalase Toko

Selanjutnya pada Gambar 11. di atas merupakan halaman input produk dan etalase toko. Saat petani menekan tambah produk pada menu akun saya atau tombol edit produk pada halaman produk saya. Maka petani akan berada di halaman tambah produk. Petani dapat mengganti dan menambahkan produk. Etalase toko yang dimaksud merupakan tampilan toko penjual pada pembeli. Halaman ini akan muncul saat pengguna menekan ikon "lihat toko". Pada tampilan rincian produk atau saat mencari toko pada kolom pencarian.

4. Halaman Cari Produk dan Rincian Produk 


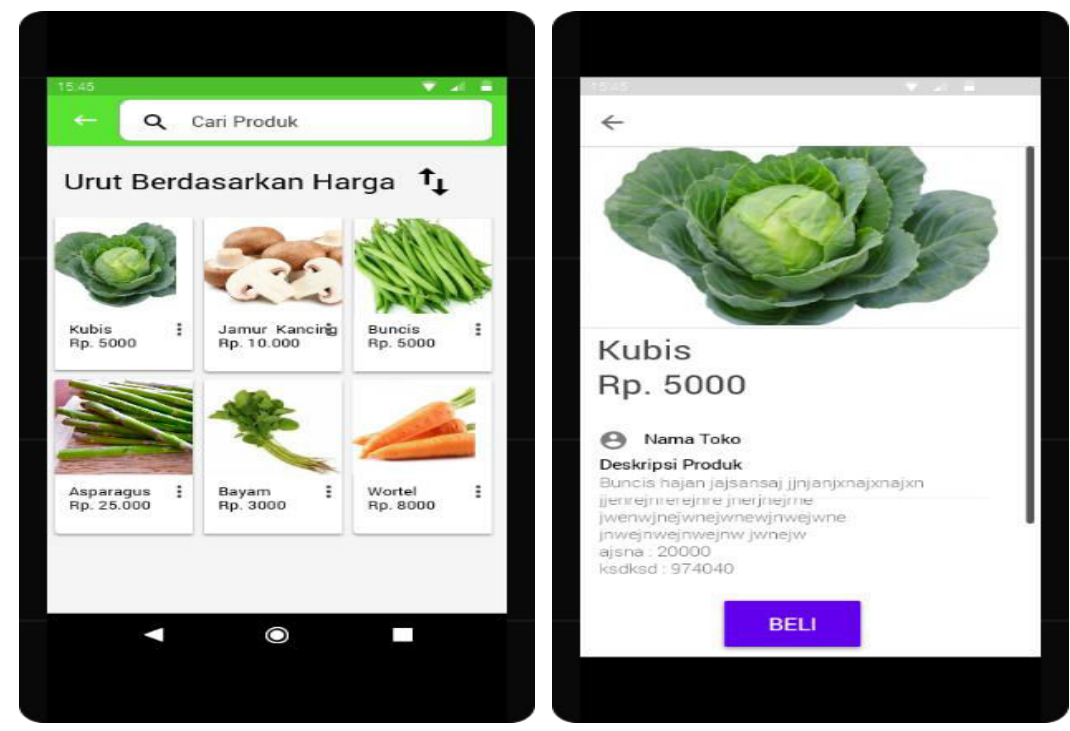

Gambar 12. Halaman Cari Produk dan Rincian Produk

Selanjutnya pada Gambar 12 di atas merupakan halaman cari produk dan rincian produk. Jika pembeli mencari produk, maka dapat di klik ikon pencarian yang terdapat dibagian atas menu home pembeli. Pada saat pembeli menekan produk, maka pembeli akan berada di halaman rincian produk. Halaman ini memuat gambar, harga dan deskripsi produk serta tombol "beli" jika pembeli tertarik untuk membeli. Kemudian saat pembeli menekan ikon "beli", maka secara otomatis pembeli akan berada di chat whatsapp petani. Chat dengan petani yang menjual produk dan melakukan transaksi melalui aplikasi whatsapp.

\section{Implement}

Tahap implementasi adalah tahap ketika aplikasi siap diperkenalkan pada pengguna dan dilakukan pengujian kelayakan aplikasi. Pada tahap ini dilakukan implementasi aplikasi Sis-Log In Apps pada beberapa smartphone masyarakat. Pengujian pada beberapa perangkat yang berbeda memiliki tujuan untuk mengetahui performa dan kompabilitas dari masing-masing perangkat tersebut ketika menjalankan Sis-Log In Apps berbasis android. Pengujian selanjutnya yaitu menggunakan metode white box testing dan black box testing. Sebelum dapat digunakan, pengguna harus memasang Sis-Log In Apps berbasis android pada smartphone.

\section{Evaluate \\ Pengujian Profitability}

Pada pengujian profitability dilakukan di 5 perangkat smartphone, mulai dari versi android 11 sampai android 5.1 dengan tujuan untuk mengetahui apakah aplikasi dapat berjalan pada berbagai macam smartphone dengan tipe android yang berbeda. Adapun pengujiannya ditunjukan pada Tabel 3 . di bawah ini:

Tabel 3. Hasil Pengujian Profitability

\begin{tabular}{|c|c|c|c|c|}
\hline No & Jenis Device & Jenis Android & $\begin{array}{l}\text { Proses } \\
\text { Instalasi }\end{array}$ & Proses Running Aplikasi \\
\hline 1 & Vivo V20 & Android 11 & $\begin{array}{l}\text { Instalasi } \\
\text { Berhasil }\end{array}$ & $\begin{array}{c}\text { Berjalan baik tanpa ada pesan } \\
\text { kesalahan (error) }\end{array}$ \\
\hline 2 & Samsung A10 & Android $9.0($ Pie $)$ & $\begin{array}{l}\text { Instalasi } \\
\text { Berhasil }\end{array}$ & $\begin{array}{c}\text { Berjalan baik tanpa ada pesan } \\
\text { kesalahan (error) }\end{array}$ \\
\hline 3 & Asus Zenfone M2 & Android 8.0 (Oreo) & $\begin{array}{l}\text { Instalasi } \\
\text { Berhasil }\end{array}$ & $\begin{array}{c}\text { Berjalan baik tanpa ada pesan } \\
\text { kesalahan (error) }\end{array}$ \\
\hline 4 & Xiaomi Mi A1 & Android 7.1 (Noughat) & $\begin{array}{l}\text { Instalasi } \\
\text { Berhasil }\end{array}$ & $\begin{array}{c}\text { Berjalan baik tanpa ada pesan } \\
\text { kesalahan (error) }\end{array}$ \\
\hline 5 & Oppo A37 & Android 5.1 (Lollipop) & $\begin{array}{l}\text { Instalasi } \\
\text { Berhasil }\end{array}$ & $\begin{array}{c}\text { Berjalan baik tanpa ada pesan } \\
\text { kesalahan (error) }\end{array}$ \\
\hline
\end{tabular}


rinci. Hal ini karena logical path (jalur logika) perangkat lunak akan dites dengan menggunakan test case. Setelah itu yang akan mengerjakan beberapa kondisi atau pengulangan secara spesifik. Pada tahap uji coba ini, dilakukan oleh Developer Sis-Log In Apps berbasis android dengan hasil secara umum sudah dapat dikatakan sesuai atau tidak terjadi error pada aplikasi. Selanjutnya Pengujian dilakukan dengan menggunakan metode black box yang diujikan pada fungsi utama dalam Sis-Log In Apps berbasis android. Dari analisis Pengujian ditemukan bahwa pengujian black box yang dilakukan mencapai target $100 \%$.

\section{KESIMPULAN}

Berdasarkan hasil Research and Development pada Sis-Log In Apps berbasis android yang telah dilakukan dengan menggunakan metode ADDIE. Maka dapat diambil beberapa kesimpulan: (1) Pengembangan Sis-Log In Apps telah berhasil dilakukan sesuai dengan rancangan kebutuhan sistem, use case diagram, activity diagram, entity relationalship diagram dan user interface. (2) Hasil pengujian terhadap Sis-Log In Apps menunjukan bahwa semua fungsi dalam aplikasi dapat berjalan baik, sesuai dengan kebutuhan pengguna. (3) Dengan adanya SisLog In Apps berbasis android, akan memudahkan konsumen untuk mencari sayuran yang dibutuhkan serta mudah menemukan lokasi para petani yang terdekat. (4) Sis-Log In Apps dapat digunakan oleh petani dalam memasarkan hasil pertanian secara langsung terhadap konsumen. Sehingga rantai distribusi pemasaran dapat dipotong, hal ini tentunya akan berimbas pada keuntungan petani.

Adapun saran pengembangan yang dapat dilakukan pada penelitian yang akan datang menambahkan lebih banyak komoditas pertanian. Serta Aplikasi dapat dibuat untuk versi sistem operasi lainnya seperti IOS. Sehingga dapat mencakup seluruh pengguna mobile device. Selain itu pembayaran juga dilakukan di luar aplikasi. Oleh karena itu sebaiknya ditambahkan fitur pembayaran melalui aplikasi dengan menggunakan mitra jasa pembayaran.

\section{UCAPAN TERIM AKASIH}

Ucapan terima kasih tersampaikan kepada Rektor Universitas Singaperbangsa Karawag, Dekan Fakultas Teknik dan Koordinator Program Studi S-1 Teknik Industri. Selain itu Kelompok Usaha Tani di Kecamatan
Telagasari, Kabupaten Karawang. Hal tersebut mendukung dan mempermudah jalannya penelitian yang dilakukan, walaupun di tengah Pandemi Covid-19.

\section{REFERENSI}

[1] Yuliana, "Corona Virus Diseases (Covid19): Sebuha Tinjauan Literatur," Wellnes and Healthy Magazine, vol. II, no. 1, pp. 187-192, 2020.

[2] World Health Organization (WHO), "World Health Organization," 2006. [Online]. Available: http://www.who.int. [Accessed 22 December 2020].

[3] F. Khairad, "Sektor Pertanian di Tengah Pandemi COVID-19 ditinjau dari Aspek Agribisnis," Jurnal Agriuma, vol. II, no. 2, pp. 82-89, 2020.

[4] D. Gusyana, "Horti Indonesia," 10 April $2020 . \quad$ [Online]. Available: http://hortiindonesia.com. [Accessed 22 December 2020].

[5] K. Sudarti, "Peningkatan Minat Pembelian Merek Lokal Melalui Etnosentrisme Konsumen," Value Added: Majalah Ekonomi dan Bisnis, vol. IX, no. 2, pp. 5769, 2013.

[6] Kussudyarsana, "Persepsi Konsumen atas Merek Lokal dan Asing pada Kategori Produk Hedonik dan Utilitarian," BENEFIT: Jurnal Managemen dan Bisnis, vol. I, no. 1, pp. 48-56, 2016.

[7] A. Setiadi, P. Yuliatmojo and D. Nurhidayat, "Pengembangan Aplikasi Android untuk Pembelajaran Pneumatik," Jurnal Pendidikan Vokasional Teknik Elektronika, vol. I, no. 1, pp. 1-5, 2018.

[8] J. Wong, Internet Marketing for Beginners, 1st ed., Jakarta: PT. Elex Media, 2010.

[9] E. Turban and J. E. Aronson, Decision Support Systems and Intelligent Systems, 7nd ed., New Jersey: Prentice Hall., 2005.

[10] J. Laudon and K. C. Laudon, Essential of Management Information System, 1st ed., New jersey: Prentice Hall, 1998.

[11] P. Brunn, M. Jensen and J. Skovgaard, "eMarketplaces: Crafting A Winning Strategy," European Management Journal, vol. XX, no. 3, pp. 286-298, 2002.

[12] A. Teguh, Membuat Interface Aplikasi Android Lebih Keren dengan LWUIT, 1st ed., Yogyakarta: Andi Offset, 2011.

[13] A. Nugroho, Rekayasa Perangkat Lunak Berorientasi Objek dengan Metode USDP (Unified Software Development Process), 
1st ed., Yogyakarta: Penerbit Andi, 2010.

[14] D. Apriadi and A. Y. Saputra, "E-Commerce Berbasis Marketplace dalam Upaya Mempersingkat Distribusi Penjualan Hasil Pertanian," Jurnal RESTI (Rekayasa Sistem dan Teknologi Informasi), vol. I, no. 2, pp. 131-136, 2017.

[15] I. M. R. S. Adinata, H. Tolle and A. H. Brata, "Pembangunan Aplikasi Penjualan Hasil Panen Kelompok Tani untuk Konsumen Berbasis Android dengan Metode Prototyping (Studi Kasus: Kelompok Tani Langgeng Mandiri)," Jurnal Pengembangan Teknologi Informasi dan IImu Komputer, vol. III, no. 7, pp. 6378-6385, 2019.

[16] M. Olivya and Ilham, "Sistem Informasi Pemasaran Hasil Pertanian Berbasis Android," Jurnal Teknologi Informasi dan Komunikasi, vol. VII, no. 1, pp. 60-69, 2017.

[17] H. Madesko, "Sistem Informasi ECommerce Pemasaran Hasil Pertanian Desa Pulau Panjang Hilir Inuman," (JuPerSaTek): Jurnal Perencanaan, Sains, Teknologi, dan Komputer, vol. II, no. 1, pp. 76-82, 2019.

[18] Ahmad, "Perancangan Aplikasi Komoditas Pertanian Berbasis Android," CSRID Journal: Computer Science Research and Its Development, vol. VII, no. 3, pp. 190200, 2015.

[19] H. Nugroho, R. Hendriyanto and K. Tisamawi, "Application for Marketplace Agricultural Product," IJAIT: International Journal of Applied Information Technology, vol. II, no. 2, pp. 56-67, 2018.

[20] C. L. Soundarya, M. Preethi, D. Kavya, S. S. Keerthana and S. Sodagudi, "Digital Farmers Market APP (DFMA) To Promote E-Trading of Agriculture," Journal of Critical Reviews, vol. VII, no. 14, pp. 2475-2480, 2020.

[21] L. Beaulah and Latha, "Android APP Solution for Farmers and Buyers to Sell and Buy Products Without Any Broker Involved," International Journal of Advanced Research
(IJAR), vol. V, no. 4, pp. 2154-2162, 2017.

[22] S. Nuanmeesri, "Mobile Application for the Purpose of Marketing, Product Distribution and Location-Based Logistics for Elderly Farmers," Applied Computing and Informatics, vol. XI, no. 1, pp. 1-9, 2019.

[23] K. Dhar, S. Barua, A. Dey and U. Barua, "(The Farmer): A Virtual Marketing Platform for Producers and Consumers of Bangladesh," International Journal of Progressive Sciences and Technologies (IJPSAT), vol. XXII, no. 1, pp. 208-214, 2020.

[24] Sugiyono, Metode Penelitian Pendidikan (Pendekatan Kuantitatif, Kualitatif dan R\&D), Bandung: Alfabeta, 2012.

[25] R. Woods, "ADDIE vs. SDLC: A Comparison In S. Carliner (Ed.)," in Proceedings of E-Learn: World Conference on E-Learning in Corporate, Government, Healthcare, and Higher Education, New Orleans, 2019.

[26] I. M. H. Antara, I. G. M. Darmawiguna and I. M. A. Pradnyana, "Pengembangan Aplikasi Mobile Crowdsourcing Informasi Layanan Umum (Studi Kasus di Kabupaten Buleleng)," Kumpulan Artikel Mahasiswa Pendidikan Teknik Informatika (KARMAPATI), vol. 8, no. 2, pp. 154-164, 2019.

[27] K. G. Turangga, I. G. M. Darmawiguna and D. G. Hendra, "Pengembangan Aplikasi Planetarium Berbasis Virtual Reality," Jurnal Nasional Pendidikan Teknik Informatika (JANAPATI), vol. 7, no. 2, pp. 207-219, 2018. 